\title{
ANL/ET/CP- 84639
}

\section{MIXED-CONDUCTING CERAMIC MEMBRANES FOR PARTIAL OXYGENATION OF METHANE*}

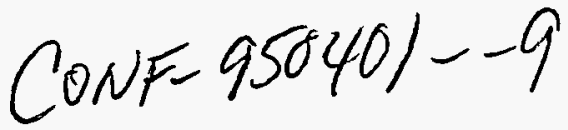

\author{
U. Balachandran, J. T. Dusek, P. S. Maiya, and R. L. Mieville \\ Energy Technology Division \\ Argonne National Laboratory \\ Argonne, IL 60439
}

M. S. Kleefisch and C. A. Udovich

Amoco Corporation

Naperville, IL 60566

\author{
A. C. Bose \\ U.S. Department of Energy \\ Pittsburgh Energy Technology Center \\ Pittsburgh, PA 15236
}

May 1995

The submitted manuscript has been authored
by a contractor of the U.S. Government
under contract No. W-3t-109ENG-38.
Accordingly, the U.S. Government retains a
nonexclusive, royalty-free license to publish
or reproduce the published form of this
contribution, or allow others to do so, for
U.S. Government purposes.

\section{DISCLAIMER}

This report was prepared as an account of work sponsored by an agency of the United States Government. Neither the United States Government nor any agency thereof, nor any of their employees, makes any warranty, express or implied, or assumes any legal liability or responsibility for the accuracy, completeness, or usefulness of any information, apparatus, product, or process disclosed, or represents that its use would not infringe privately owned rights. Reference herein to any specific commercial product, process, or service by trade name, trademark, manufacturer, or otherwise does not necessarily constitute or imply its endorsement, recommendation, or favoring by the United States Government or any agency thereof. The views and opinions of authors expressed herein do not necessarily state or reflect those of the United States Government or any agency thereof.

For presentation at the 97th Annual Meeting of the American Ceramic Society, April 30-May 4, 1995, Cincinnati, OH.

*Work at Argonne National Laboratory is supported by the U.S. Department of Energy, Pittsburgh Energy Technology Center, under Contract W-31109-Eng-38. 


\section{DISCLAIMER}

Portions of this document may be illegible in electronic image products. Images are produced from the best available original document. 


\section{MIXED-CONDUCTING CERAMIC MEMBRANES FOR PARTIAL OXYGENATION OF METHANE}

U. Balachandran, J. T. Dusek, P. S. Maiya, and R. L. Mieville Energy Technology Division Argonne National Laboratory Argonne, IL 60439

M. S. Kleefisch and C. A. Udovich Amoco Corporation Naperville, IL 60566

\section{A. C. Bose}

U.S. Department of Energy

Pittsburgh Energy Technology Center

Pittsburgh, PA 15236

\section{INTRODUCTION}

Mixed-oxide conductors find wide application in high-temperature solid-state electrochemical devices such as solid-oxide fuel cells, batteries, and sensors. The same materials also hold particular promise as ceramic membranes designed to separate oxygen from air, because they are impervious to other gaseous constituents. High oxygen permeability, usually associated with high oxygen ionic conductivity, is desirable in the separation

process. $(\mathrm{La}, \mathrm{Sr})(\mathrm{Fe}, \mathrm{Co}) \mathrm{O}_{\mathbf{x}}$ systems have been shown by Teraoka et al. $[1,2]$ to exhibit not only mixed (electronic and ionic) conductivities but also appreciable oxygen permeability (two orders of magnitude higher than that of stabilized zirconia at $800^{\circ} \mathrm{C}$ ).

No external electrodes are required for oxygen separation in these systems, which will operate without an external applied potential. Furthermore, the oxygen flux obtainable from the separation of air is 
considered commercially feasible for syngas generation by the partial oxidation of methane [3-7]. The most significant cost associated with the conventional partial oxidation of methane is that of an oxygen plant. Our new technology offers a way to lower this cost, and in this paper we explore the technology that is based on dense ceramic membranes and that uses air as the oxidant for methane-conversion reactions.

\section{EXPERIMENTAL}

Three ceramic powders (SFC-1, SFC-2, and SFC-3) in the La-Sr-FeCo-O system, with different stoichiometries, were made by solid-state reaction of the constituent cation salts. The stoichiometry of SFC-1 is $\mathrm{La}_{0.2} \mathrm{Sr}_{0.8} \mathrm{Fe}_{0.6} \mathrm{Co}_{0.4} \mathrm{O}_{x}$, which has been reported by Teraoka et al. [1,2]. The stoichiometry of SFC-2, an improved version of SFC-1, is $\mathrm{SrFeCo}_{0.5} \mathrm{O}_{x}$, and that of $\mathrm{SFC}-3$ is $\mathrm{SrFe}_{0.2} \mathrm{Co}_{0.8} \mathrm{O}_{\mathrm{x}}$. All three powders were made by mixing appropriate amounts of $\mathrm{La}\left(\mathrm{NO}_{3}\right)_{3}, \mathrm{SrCO}_{3}, \mathrm{Co}\left(\mathrm{NO}_{3}\right)_{2} \cdot 6 \mathrm{H}_{2} \mathrm{O}$, and $\mathrm{Fe}_{2} \mathrm{O}_{3}$ and grinding in isopropanol with $\mathrm{ZrO}_{2}$ media for $15 \mathrm{~h}$. After drying, the mixtures were calcined in air at $850^{\circ} \mathrm{C}$ for $16 \mathrm{~h}$ with intermittent grinding. After final calcination, the powders were ground with an agate mortar and pestle to an average particle size of $\approx 7 \mu \mathrm{m}$. The resulting powders were characterized by X-ray diffraction (XRD), scanning electron microscopy, and thermal analysis, and analyzed for particle-size distribution.

The powder was made into a slip containing a solvent, dispersant, binder, and plasticizer. Membrane tubes were fabricated by extruding the slip to an outside diameter of $\approx 6.5 \mathrm{~mm}$, lengths up to $\approx 30 \mathrm{~cm}$, and wall thicknesses of $0.25-1.20 \mathrm{~mm}$. The tubes were sintered at $\approx 1200^{\circ} \mathrm{C}$ for 5-10 $\mathrm{h}$ in stagnant air. 
Mechanical properties of the finished material were measured by conventional methods, i.e., bulk density was measured by the Archimedes principle; flexural strength, in a four-point bending mode; fracture toughness, by a single-edge notch method [8]; and Young's modulus, shear modulus, and Poisson ratio, by ultrasonic methods [9]. The thermal expansion coefficient was measured in a dilatometer.

The ceramic materials were evaluated for performance in a quartz reactor system, as shown in Fig. 1. The quartz reactor supports the ceramic membrane tube with Pyrex hot seals. This design creates an isothermal environment for the ceramic tube. To facilitate reactions and equilibration of gases in the reactor, an Rh-based reforming catalyst is loaded adjacent to the tube. Gold wire mesh is wrapped around the tube to prevent solid-state reactions between the catalyst and the ceramic. Both feed gas and effluents were analyzed by gas chromotography.

Samples were prepared for conductivities and diffusional measurements by compressing the constituent powders at $1.2 \times 10^{3} \mathrm{MPa}$ into pellets $21.5 \mathrm{~mm}$ in diameter and $\approx 3 \mathrm{~mm}$ thick. Pellets were sintered in air at $\approx 1200^{\circ} \mathrm{C}$ for $5 \mathrm{~h}$; they were then cut into small bars. The bulk densities of samples are $\approx 95 \%$ of their theoretical values.

Platinum wires were used as probes in the four-probe conductivity measurement. Specimen resistance was measured with an HP 4192A LF impedance analyzer. For measurement of oxygen ion conduction, yttriastabilized zirconia ( $\mathrm{YSZ}$, with $8 \mathrm{~mol} \% \mathrm{Y}_{2} \mathrm{O}_{3}$ ) was used for the electron (hole) blocking electrode [10]. 
The oxygen diffusion coefficient was measured by a relaxation method. The sample was subjected to a sudden change in oxygen partial pressure and ionic conductivity was monitored as a function of time and temperature [11]. RESULTS AND DISCUSSION

Tubes of SFC-1 lasted only a few minutes when operated as a conversion reactor at $850^{\circ} \mathrm{C}$; they then broke into several pieces. XRD patterns of the original samples of $\mathrm{SFC}-1$ were recorded at $850^{\circ} \mathrm{C}$ in $\mathrm{Ar}-\mathrm{O}_{2}$ gas mixtures. The phase behavior of SFC-1 in 1 and $20 \% \mathrm{O}_{2}$ is shown in Fig. 2. In an oxygen-rich $\left(20 \% \mathrm{O}_{2}\right)$ atmosphere, the material was a cubic perovskite. However, once the oxygen partial pressure was lowered below 5\%, the cubic phase transformed to an oxygen-vacancy-ordered phase. New peaks appeared in the XRD pattern, as seen in Fig. $2\left(1 \% \mathrm{O}_{2}\right)$. It is important to note that this material expanded substantially after the phase transition; this can be seen from the change in the position of the Bragg peak near $32^{\circ}$. Evidently, this peak in the oxygen-vacancy-ordered phase (in $1 \% \mathrm{O}_{2}$ ) was shifted to the low-angle (larger $\mathrm{d}$-spacing) side of the corresponding peak in the cubic perovskite phase (in $20 \% \mathrm{O}_{2}$ ).

Detailed thermogravimetric analysis (TGA) [12] showed that the oxygen content, $\mathrm{x}$, of the SFC-1 sample in $1 \% \mathrm{O}_{2}$ was $\approx 0.1$ lower than that in a sample in $20 \% \mathrm{O}_{2}$. Dependence of the unit cell volume on oxygen content of the sample has been established by comparing lattice parameters. For example, the volume of the primitive perovskite cell, $V_{p}$, is $57.51 \AA^{3}$ for $x=2.67$ and $59.70 \AA^{3}$ for $x=2.48$. These results show that this material expands as oxygen is removed. Such behavior suggests that an electronic effect is predominant in influencing the specific volume; otherwise, a simple 
size effect would cause the lattice to shrink. By linear interpolation of the above results, we predict that a decrease in $x$ of 0.1 will result in an increase in $V_{p}$ by $\approx 2 \%$.

Both XRD results and TGA data [12] give a clear picture of the state of SCF-1 under reaction conditions. When the membrane tube is operating, high oxygen pressure is maintained outside the tube and low oxygen pressure is maintained inside the tube. Before the tube is brought up to high temperature, oxygen distribution is uniform. Upon heating, the tube material begins to lose oxygen that was incorporated during the fabrication process. Moreover, the material on the inner wall loses more oxygen than that on the outer wall. As a result, a stable oxygen gradient is generated between the outer and inner walls. It follows that the material, depending on its location in the tube, may contain different phase constituents. It is probable that the inner zone of lower oxygen content contains more ordered oxygen vacancies and hence less oxygen permeability.

The most remarkable factor, which can cause tube fracture, appears to be the lattice mismatch between the materials on the inner and outer walls of the tube. The difference in composition between the inner and outer zones leads to an expansion of $2 \%$, which is equivalent to thermal expansion caused by a $333^{\circ} \mathrm{C}$ temperature increase.

In comparison, SFC-2 exhibited a remarkable structural stability at high temperature, as shown in Fig. 3. No phase transition was observed in this material as oxygen partial pressure was changed. Furthermore, the Bragg peaks stayed at the same position regardless of the oxygen partial pressure 
of the atmosphere. The physical and mechanical properties of SFC-2 are shown in Table 1.

Table 1. Physical and mechanical properties of SFC-2

\begin{tabular}{lc}
\hline \multicolumn{1}{c}{ Property } & Value \\
\hline Bulk density, $\mathrm{g} \cdot \mathrm{cm}^{-3}$ & $4.81 \pm 0.04$ \\
Percent of theoretical density & 93 \\
$\begin{array}{l}\text { Coefficient of thermal expansion } \mathrm{x} \\
10^{-6} /{ }^{\circ} \mathrm{C}\left(200-800^{\circ} \mathrm{C}\right)\end{array}$ & 14.0 \\
Flexural strength, $\mathrm{MPa}$ & $120.4 \pm 6.8$ \\
Fracture toughness, $\mathrm{MPa} \sqrt{\mathrm{m}}$ & $2.04 \pm 0.06$ \\
Young's modulus, GPa & $124 \pm 3$ \\
Shear modulus, GPa & $48 \pm 2$ \\
Poisson ratio & $0.30 \pm 0.01$ \\
\hline
\end{tabular}

Figure 4 shows the probability of failure vs. flexural strength (Weibull statistics) for SFC-2 [13]. The Weibull modulus was 15, indicating only moderate scatter in the strength data. Measured room-temperature properties were used to develop failure criteria for the membranes under actual reaction conditions in a plant where methane is expected to be at higher pressures. Figure 5 shows the computed allowable external pressure on SFC-2 as a function of tube wall thickness. These calculations were based on the assumptions that the tensile strength is $\approx 0.67$ times the flexural stress and that the compressive strength of SFC-2 is greater than its tensile strength by a factor of 8 . These results suggest an ability of this ceramic 
material to undergo reasonable stresses that might occur in a commercial reactor. Tubes made of this material, unlike those made of SFC-1, are not expected to fracture under reactor conditions.

Differences between SFC-2 and SFC-3 are seen in their electronic and ionic conductivities shown in Table 2, together with those of other materials of this same type. It is clear that SFC-2 is unique in that the ratio of ionic to electronic conductivity is close to unity.

Table 2. Conductivities measured in air at $800^{\circ} \mathrm{C}$ for $(\mathrm{La}, \mathrm{Sr})(\mathrm{Fe}, \mathrm{Co}) \mathrm{O}_{\mathrm{x}}$ systems

\begin{tabular}{|c|c|c|c|c|}
\hline Sample & $\begin{array}{l}\text { Electronic } \\
\sigma_{\mathrm{el}}\left(\mathrm{S} \cdot \mathrm{cm}^{-1}\right)\end{array}$ & $\begin{array}{l}\text { Ionic } \sigma_{\mathbf{i}} \\
\left(\mathrm{S} \cdot \mathrm{cm}^{-1}\right)\end{array}$ & $\begin{array}{l}\text { Method for } \sigma_{\mathbf{i}} \\
\text { measurement }\end{array}$ & Ref. \\
\hline SFC-2 & 10 & 7 & $\begin{array}{l}\text { 4-terminal, YSZ } \\
\text { electron block }\end{array}$ & 10 \\
\hline SFC-3 & 76 & 4 & $\begin{array}{l}\text { 4-terminal, YSZ } \\
\text { electron block }\end{array}$ & 10 \\
\hline $\mathrm{La} .6 \mathrm{Sr}_{.4} \mathrm{Co}_{.2} \mathrm{Fe}_{.8} \mathrm{O}_{3}$ & 300 & 0.01 & $\begin{array}{l}\text { 4-terminal, YSZ } \\
\text { electron block }\end{array}$ & 14 \\
\hline $\mathrm{La} .6 \mathrm{Sr}_{0.4} \mathrm{Co}_{.2} \mathrm{Fe}_{0.8} \mathrm{O}_{3}$ & 300 & 0.003 & $\begin{array}{l}\text { 2-terminal, } \\
\text { electron block }\end{array}$ & 15 \\
\hline $\mathrm{La}_{0.8} \mathrm{Sr}_{0.2} \mathrm{Co}_{0.8} \mathrm{Fe}_{0.2} \mathrm{O}_{3}$ & 600 & 15 & $\begin{array}{l}\text { 4-terminal, YSZ } \\
\text { electron block }\end{array}$ & 16 \\
\hline $\mathrm{La}_{.8} \mathrm{Sr}_{0.2} \mathrm{Co}_{0.8} \mathrm{Fe}_{.2} \mathrm{O}_{3}$ & 250 & 0.10 & $\begin{array}{l}\text { 4-terminal, YSZ } \\
\text { electron block }\end{array}$ & 17 \\
\hline $\mathrm{La}_{0.75} \mathrm{Sr}_{0.25} \mathrm{FeO}_{3}$ & 50 & 0.03 & $\begin{array}{l}18 \mathrm{O} / 16 \mathrm{O} \\
\text { exchange }\end{array}$ & 18 \\
\hline
\end{tabular}

Furthermore, limited SFC-2 diffusion data obtained from the timerelaxation method [11] indicate that transport of oxygen ions is associated with an activation energy of $0.89 \mathrm{eV}$. This is consistent with the high diffusion coefficient of $9 \times 10^{-7} \mathrm{~cm}^{2} \mathrm{~s}^{-1}$ at $900^{\circ} \mathrm{C}$. 
Performance in generating syngas is demonstrated in Fig. 6, which shows conversion data obtained with an SFC-2 membrane tube operated at $850^{\circ} \mathrm{C}$ for $\approx 70 \mathrm{~h}$. As shown, methane conversion efficiency is $>98 \%$, and CO selectivity is $90 \%$. Measured $\mathrm{H}_{2}$ yield is about twice that of $\mathrm{CO}$ as expected.

The role of the catalyst in the transport of oxygen across the membrane of an SFC-2 tube was tested without the reforming catalyst. The results from a run of $\approx 350 \mathrm{~h}$ are shown in Fig. 7 . The feed gases are the same as before. In the absence of a catalyst, the oxygen that was transported through the membrane reacted with methane and formed $\mathrm{CO}_{2}$ and $\mathrm{H}_{2} \mathrm{O}$. As seen in Fig. 8 , methane conversion efficiency was $\approx 35 \%$ and $\mathrm{CO}_{2}$ selectivity was $\approx 90 \%$. Under our operating conditions, the measured oxygen flux was $\approx 0.3 \mathrm{std} \mathrm{cm}^{3} / \mathrm{cm}^{2} / \mathrm{min}$. Figure 8 shows the result of a reactor run made under more severe conditions and in the presence of a catalyst for $>500 \mathrm{~h}$. Conversion and selectivities are similar to those of the $350 \mathrm{~h}$ run but the oxygen flux was one order of magnitude greater. Some small deactivation in oxygen permeation rate was observed.

Further confirmation of the stability of this membrane tube is shown in Fig. 9, which shows the reactor results over a period of $1000 \mathrm{~h}$. The feed during this period was a typical mixture expected in a commercial recycle feed, namely methane, $\mathrm{CO}, \mathrm{CO}_{2}$, and $\mathrm{H}_{2}$. Throughout the run, methane conversion was high. A small decline in oxygen permeation was observed. However, this high oxygen flux is consistent with the high diffusion coefficient of $9 \times 10^{-7} \mathrm{~cm}^{2} \mathrm{~s}^{-1}$ measured by the time-relaxation method [11]. 


\section{CONCLUSIONS}

Mixed-conducting ceramic materials have been produced from mixedoxide systems of the $\mathrm{La}-\mathrm{Sr}-\mathrm{Fe}-\mathrm{Co}-\mathrm{O}$ (SFC) type, in the form of tubes and bars. Thermodynamic stability of the tubes was studied as a function of oxygen partial pressure by high-temperature XRD. Mechanical properties were measured and found to be adequate for a reactor in the case of SFC-2. Electronic and ionic conductivities were measured; SFC-2 is unique in the sense that the ratio of ionic to electronic conductance is close to unity.

Performance of the membrane tubes was good only with SFC-2. Fracture of other SFC tubes was the consequence of an oxygen gradient that introduced a volumetric lattice difference between the inner and outer walls. SFC-2 tubes provided methane conversion efficiencies of $>99 \%$ in a reactor. These tubes have operated for $>1000 \mathrm{~h}$.

ACKNOWLEDGMENTS

Work at Argonne National Laboratory is supported by the U.S. Department of Energy, Pittsburgh Energy Technology Center, under Contract W-31-109-Eng-38.

\section{REFERENCES}

1. Y. Teraoka, H. M. Zhang,-S. Furukawa, and N. Yamozoe, Chem. Lett., 1985, 1743, 1985.

2. Y. Teraoka, T. Nobunaga, and N. Yamazoe, Chem. Lett., 1988, 503, 1988. 
3. U. Balachandran, S. L. Morissette, J. J. Picciolo, J. T. Dusek, R. B. Poeppel, S. Pei, M. S. Kleefisch, R. L. Mieville, T. P. Kobylinski, and C. A. Udovich, Proc. Int. Gas Research Conf., (H. A. Thompson, ed.) pp. 565-573, Government Institutes, Inc., Rockville, MD, 1992.

4. T. J. Mazanec, T. L. Cable, and J. G. Jr. Frye, Solid State Ionics, 111, $53,1992$.

5. A. C. Bose, J. G. Stigel, and R. D. Srivastava, "Gas to Liquids Research Program of the U.S. Department of Energy: Programmatic Overview," paper presented at the Symposium on Alternative Routes for the Production of Fuels, American Chemical Society National Meeting, Washington DC, Aug. 21-26, 1994.

6. U. Balachandran, S. L. Morissette, J. T. Dusek, R. L. Mieville, R. B. Poeppel, M. S. Kleefisch, S. Pei, T. P. Kobylinski, and C. A. Udovich, Proceedings of Coal Liquefaction and Gas Conversion Contractors Review Conference (S. Rogers et al., eds.), Vol. 1, pp. 138-160, U.S. Department of Energy, Pittsburgh Energy Technology Center, Pittsburgh, PA, Sept. 27-29, 1993.

7. T. L. Cable, European Patent EP 0438902 A2, July 31, 1991.

8. W. F. Brown, Jr. and J. E. Strawley, ASTM STP 410, Philadelphia, PA, 1967.

9. J. Kraütkramer and H. Kraütkramer, Ultrasonic Testing of Materials (Springer-Verlag, NY, 1983). 
10. B. Ma, J.-H. Park, U. Balachandran, and C. U. Segre, "Electronic/Ionic Conductivity and Oxygen Diffusion Coefficient of the Sr-Fe-Co-O System," Materials Research Society Spring Meeting, San Francisco, CA, April 17-21, 1995.

11. B. Ma, U. Balachandran, J.-H. Park, and C. U. Segre, submitted to Solid State Ionics.

12. S. Pei, M. S. Kleefisch, T. P. Kobylinski, J. Faber, C. A. Udovich, V. Zhang-McCoy, B. Dabrowski, U. Balachandran, R. L. Mieville, and R. B. Poeppel, Catalysis Letters, 30, 201, 1995.

13. W. Weibull, J. Appl. Mech., 293, 18, 1951.

14. H. U. Anderson, C. C. Chen, L. W. Tai, and M. M. Nasrallah, Proc. 2nd Intl. Symp. on Ionic and Mixed Conduction Ceramics edited by T. A. Ramanarayaman, W. L. Worrell, and H. L. Tuller (The Electrochem. Soc., 1994), pp. 376-387.

15. C. C. Chen, M. M. Nasrallah, and H. U. Anderson, submitted to J. Electrochem. Soc., 1994.

16. W. L. Worrell, P. Han, and J. Huang, in High Temperature Electrochemical Behavior of Fast Ion and Mixed Conductors, (F. W. Poulsen, J. J. Bertzen, T. Jacobson, E. Skou, and M. J. L. Ostergood, eds.) (Risø National Laboratory, 1993), pp. 461-466,

17. Y. Teraoka, H. M. Zhang, K. Okamoto, and N. Yamazoe, Mat. Res. Bull., 23, 51, 1988.

18. T. Ishigaki, S. Yamauchi, K. Kishio, J. Mizusaki, and K. Fuek, Solid State Chem. 73, 179, 1988. 


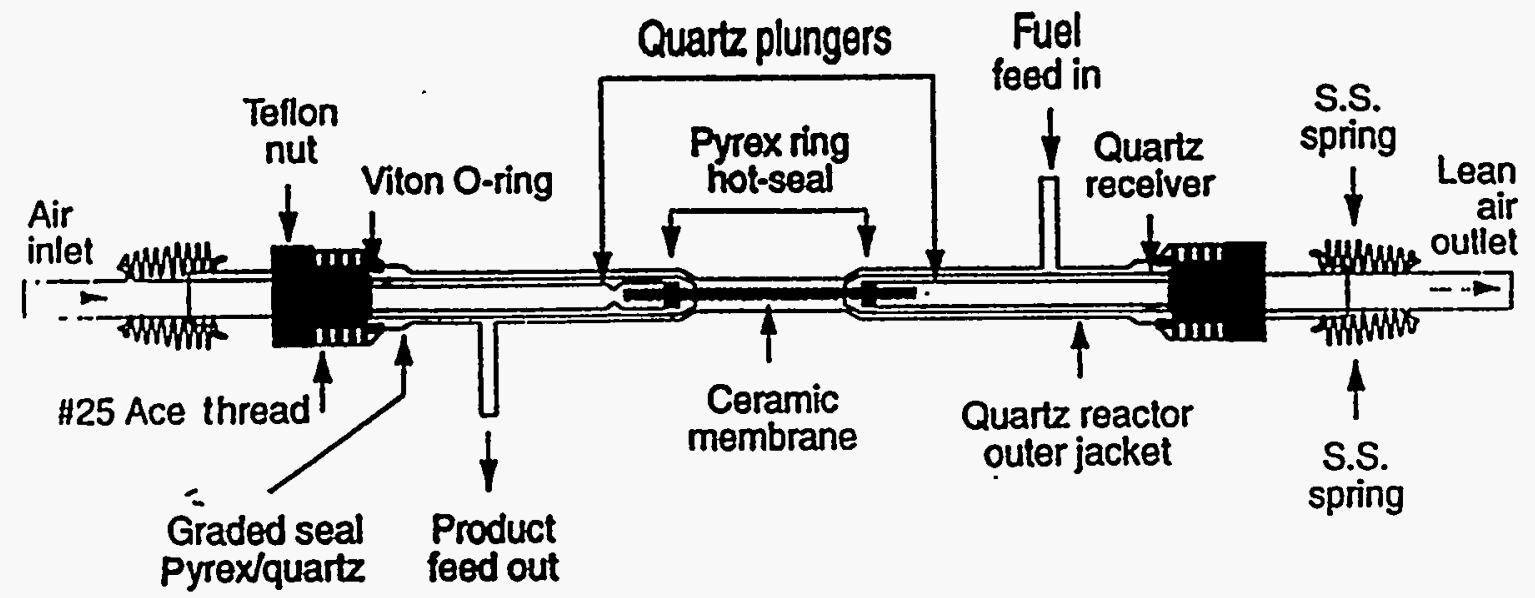

Fig. 1. Schematic diagram of ceramic membrane reactor.

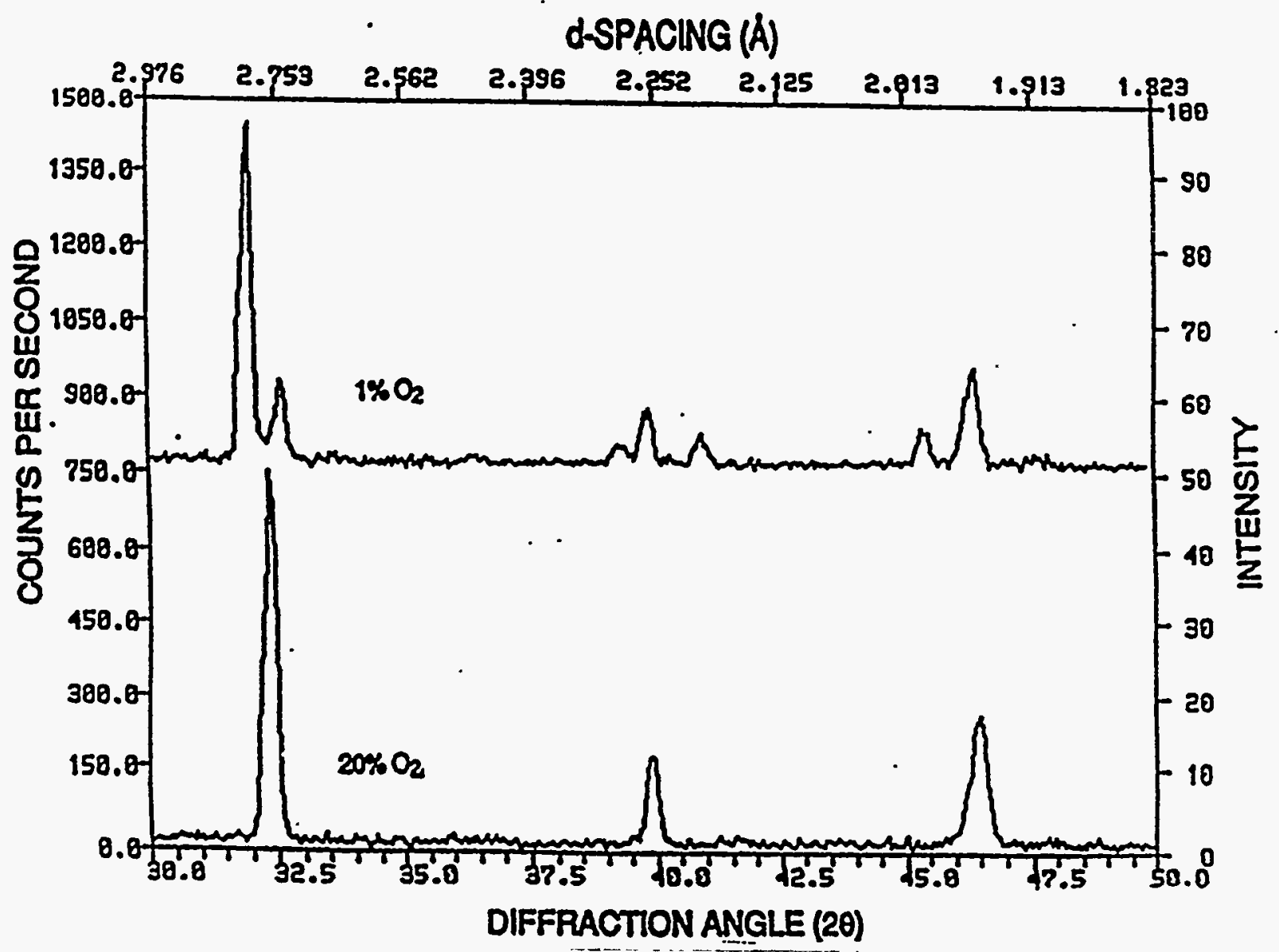

Fig. 2. XRD of SFC-1 at $850^{\circ} \mathrm{C}$ in 1 and $20 \% \mathrm{O}_{2}$ (balance is $\mathrm{Ar}$ ). 


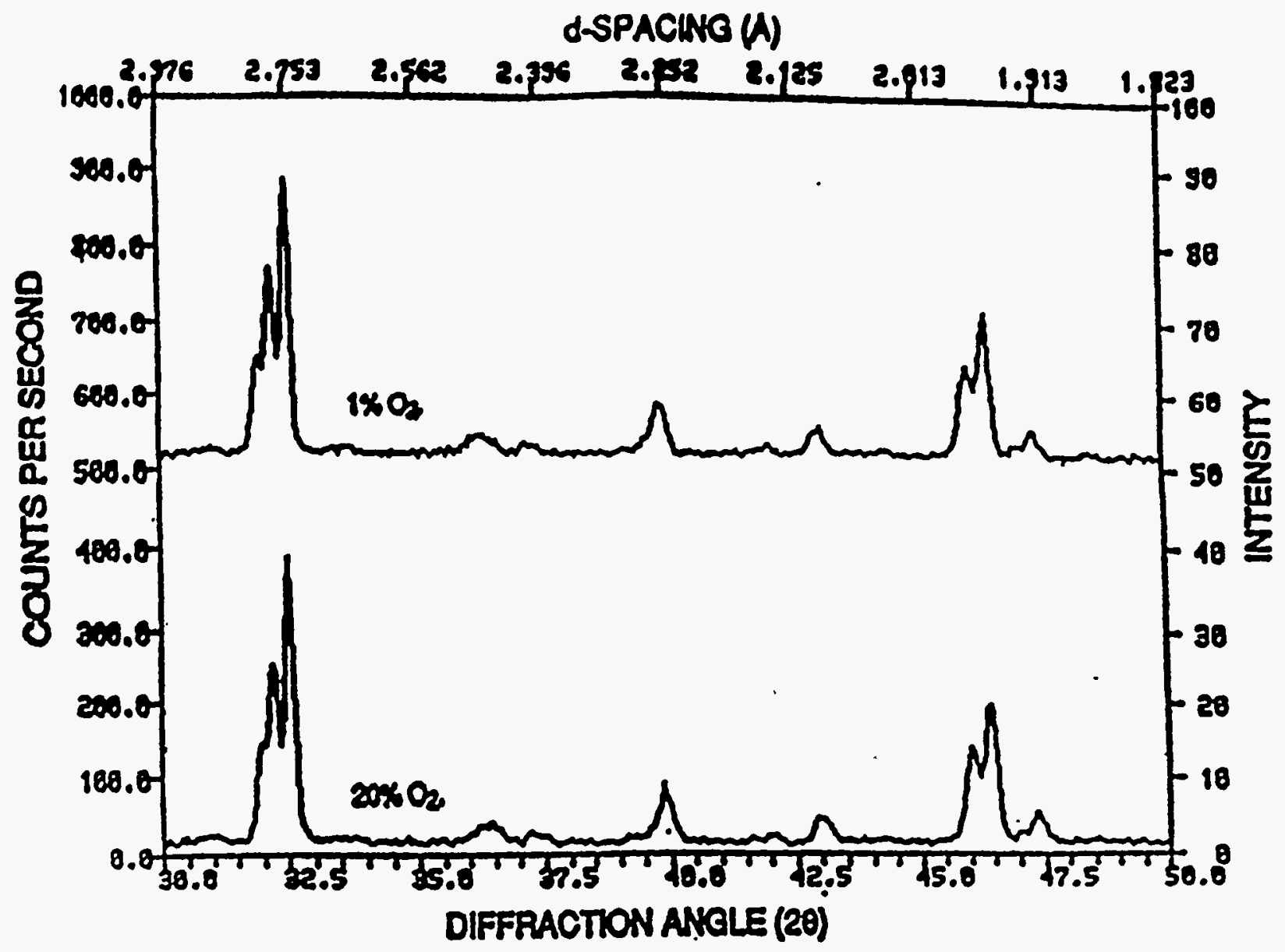

Fig. 3. XRD of $\mathrm{SFC}-2$ at $850^{\circ} \mathrm{C}$ in 1 and $20 \% \mathrm{O}_{2}$ (balance is $\mathrm{Ar}$ ).

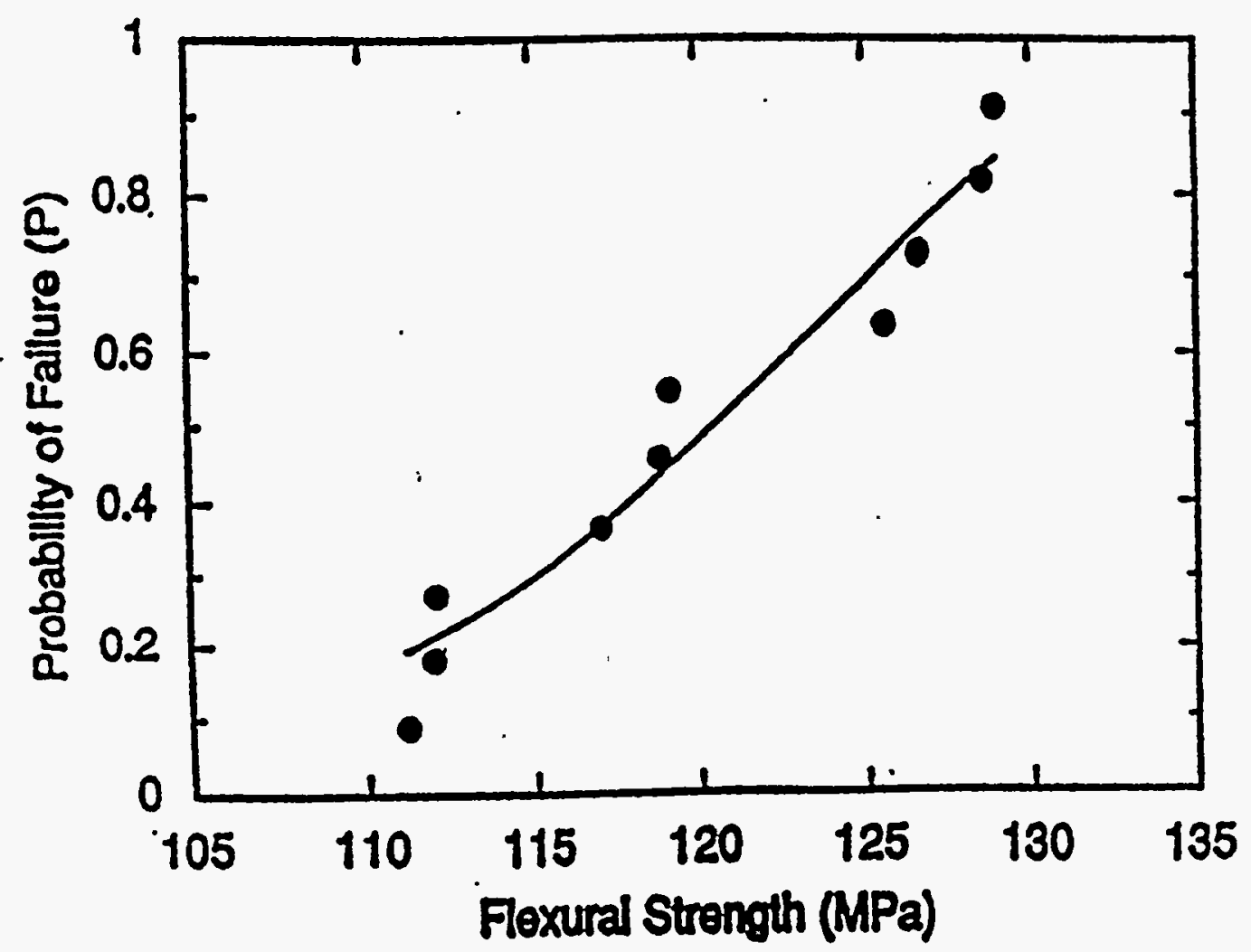

Fig. 4. Probability of failure vs. flexural strength for SFC-2 (Weibull modulus $=14.5$ ) . 


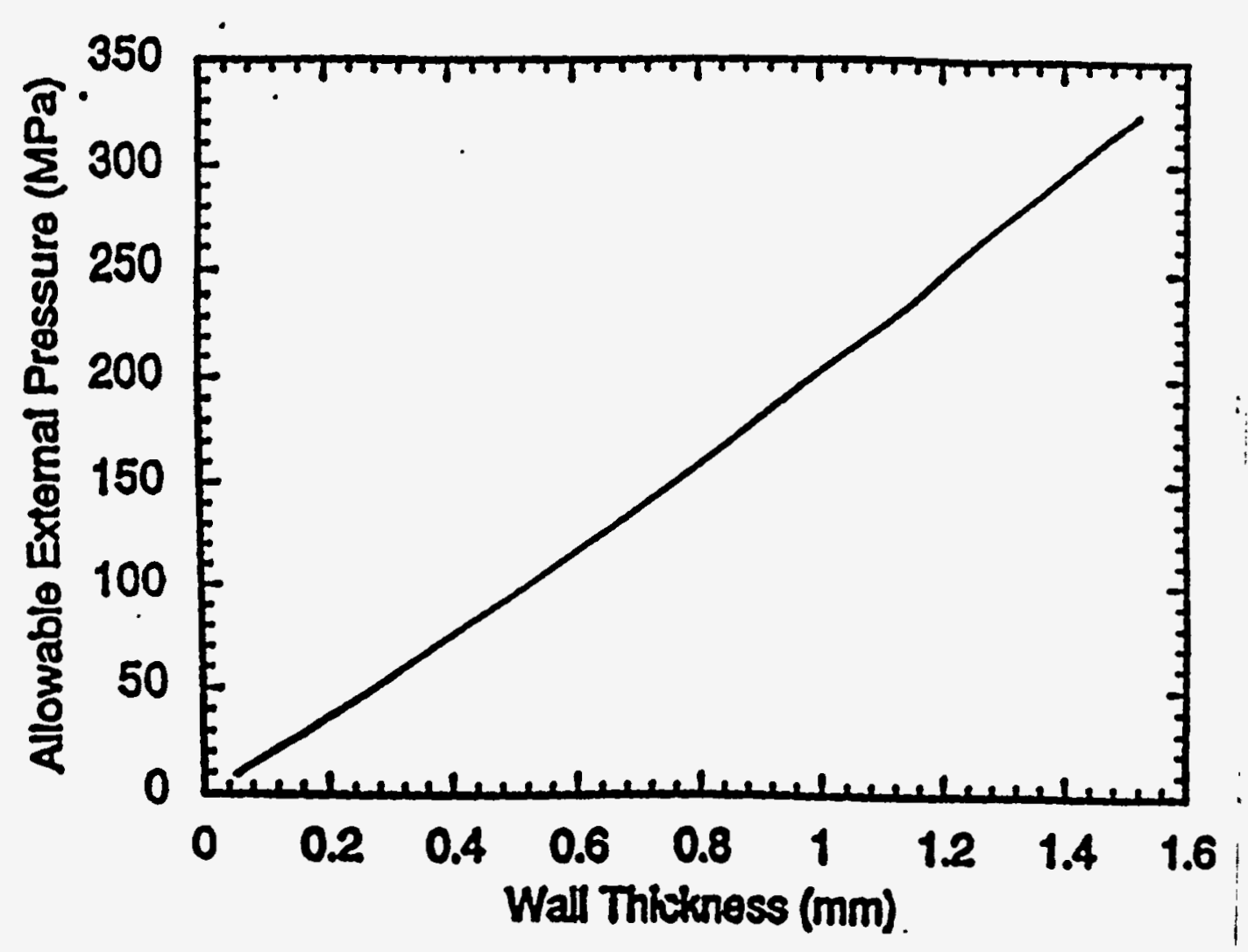

Fig. 5. Allowable external pressure on SFC-2 tubes as a function of wall thickness (outside diameter $=6.40 \mathrm{~mm}$ ).

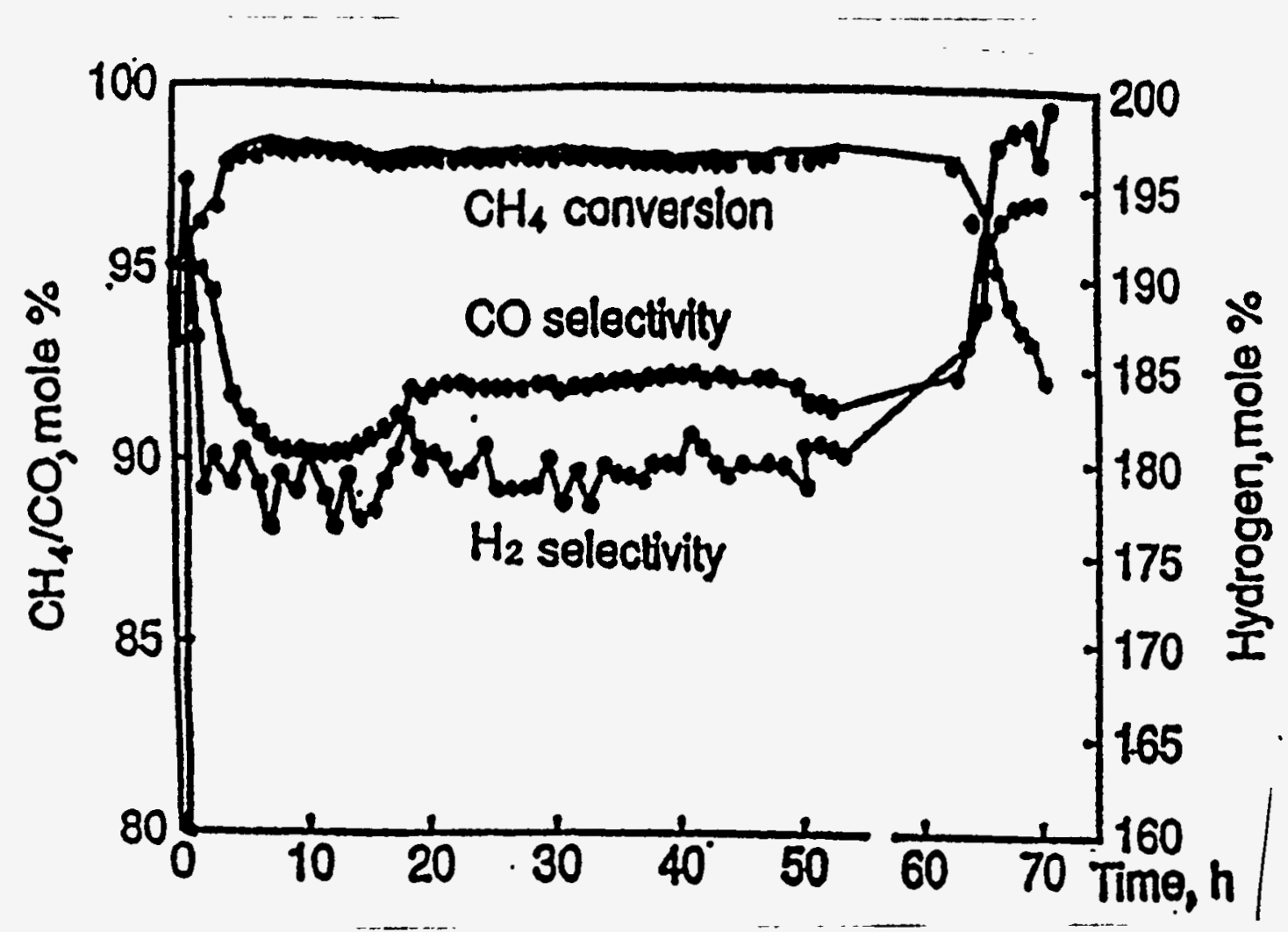

Fig. 6. Methane conversion and $\mathrm{CO}$ and $\mathrm{H}_{2}$ selectivities in SFC-2 membrane reactor with reforming catalyst. Conditions: feed $(80 \%$ $\mathrm{CH}_{4}, 20 \% \mathrm{Ar}$ ) flow, $2.5 \mathrm{~cm}^{3} / \mathrm{min}$; temp., $850^{\circ} \mathrm{C}$; pressure $1 \mathrm{~atm}$; membrane surface area, $10 \mathrm{~cm}^{2}$. 

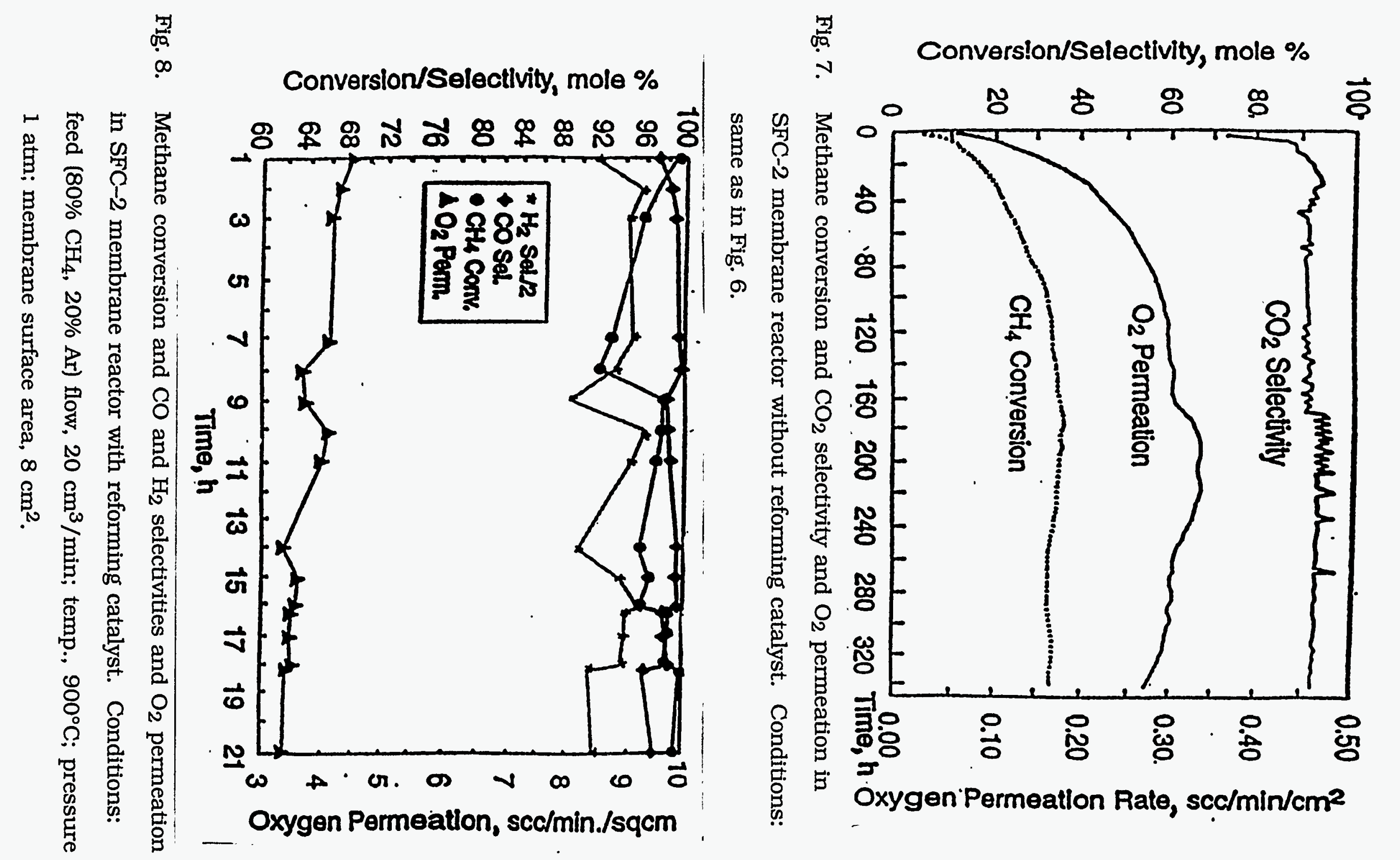


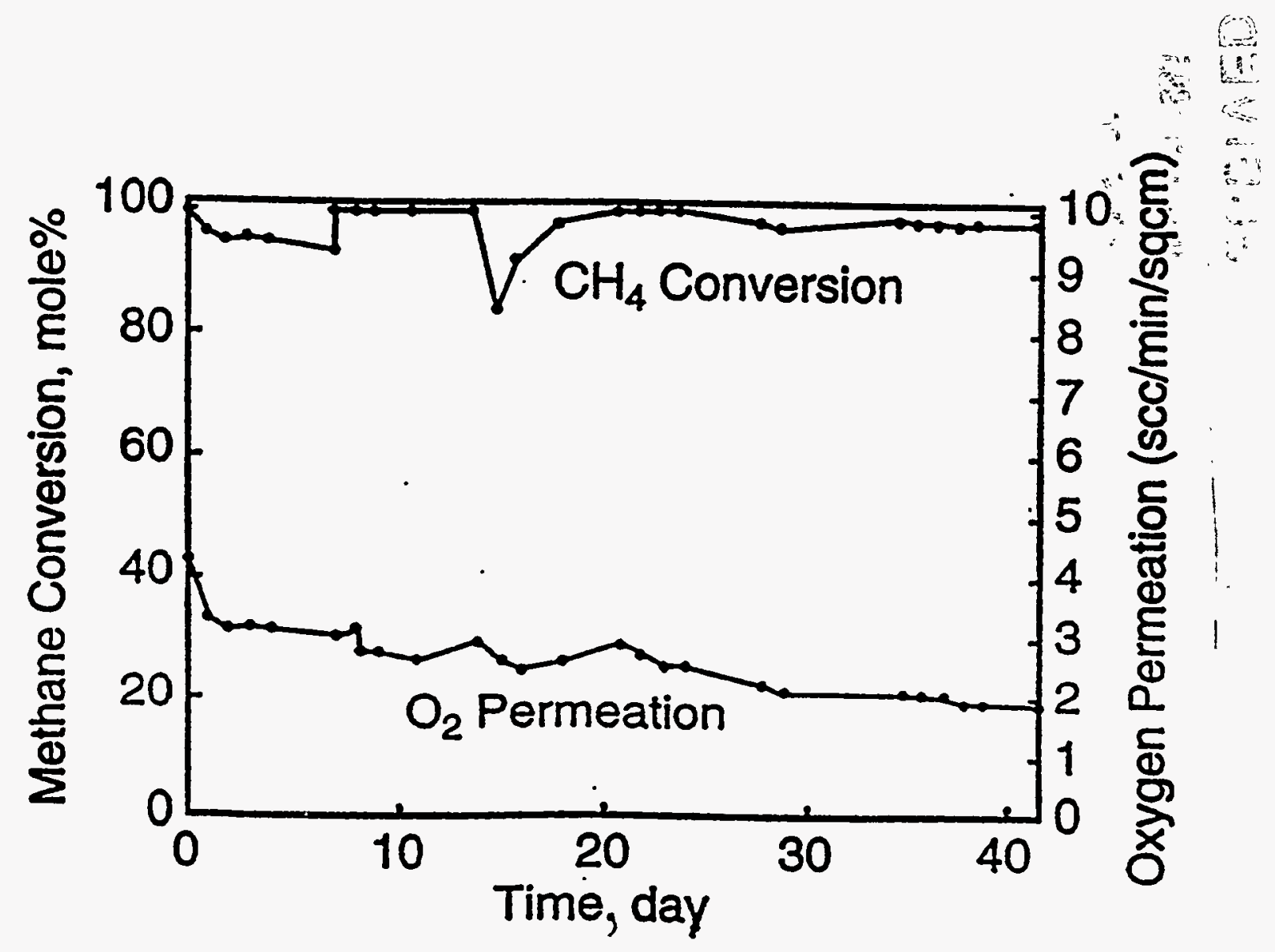

Fig. 9. Methane conversion and $\mathrm{O}_{2}$ flux for a mixed feed. Conditions: feed ( $80 \% \mathrm{CH}_{4}, 20 \% \mathrm{Ar}$ ); temp., $900^{\circ} \mathrm{C}$; pressure 1 atm; catalyst, $1.5 \mathrm{~g}$; membrane surface area, $8.4 \mathrm{~cm}^{2}$. 